\title{
Acid mine drainage from the Panasqueira mine and its influence on Zêzere river (Central Portugal)
}

\author{
Carla Candeias $^{\mathrm{a}, *}$, Paula Freire Ávila ${ }^{\mathrm{b}}$, Eduardo Ferreira da Silva ${ }^{\mathrm{a}}$, Adelaide Ferreira ${ }^{\mathrm{b}}$, Ana Rita Salgueiro ${ }^{\mathrm{a}}$, \\ João Paulo Teixeira ${ }^{c}$

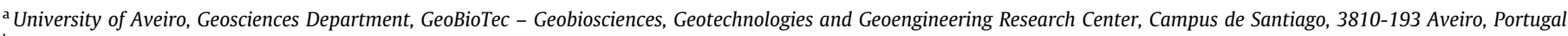 \\ ${ }^{\mathrm{b}}$ LNEG-National Laboratory of Energy and Geology, 4465-956 S. Mamede Infesta, Portugal \\ ${ }^{\mathrm{c}}$ National Institute of Health, Environmental Health Department, Rua Alexandre Herculano, 321, 4000-055 Porto, Portugal
}

\section{A R T I C L E I N F O}

Article history:

Available online 25 October 2013

\section{Keywords:}

Acid mine drainage

Geochemical modeling

Hydrogeochemistry

Mineralogy

Panasqueira mine

\begin{abstract}
A B S T R A C T
The Panasqueira hydrothermal mineralization, located in central Portugal, is the biggest Sn-W deposit of the Western Europe. The main evidences of the mining exploitation and ore treatment operations are testified with huge tailings, mainly, in the Rio and Barroca Grande areas. The mining and beneficiation processes, at the site, produces metal rich mine wastes. Oxidation of sulfides tailings and flow from open impoundments are responsible for the mobilization and migration of metals from the mine wastes into the environment. Acid mine drainage (AMD) discharged from Rio tailing has a $\mathrm{pH}$ around 3 and high metal concentrations. In Zêzere river, Fe and As are the most rapidly depleted downstream from AMD once As adsorbs, coprecipitate and form compounds with iron oxyhydroxides. The Zêzere river waters are oversaturated with respect to kaolinite and goethite and ferrihydrite can precipitate on stream with a near-neutral $\mathrm{pH}$. At sites having low $\mathrm{pH}$ the dissolved Fe species in the water, mainly, occur as sulfate complexes due to a high $\mathrm{SO}_{4}$ concentration. Melanterite $\left(\mathrm{Fe}^{2+}\left(\mathrm{SO}_{4}\right) \cdot 7\left(\mathrm{H}_{2} \mathrm{O}\right)\right)$ and minor amounts of rozenite $\left(\mathrm{Fe}^{2+}\left(\mathrm{SO}_{4}\right) \cdot 4\left(\mathrm{H}_{2} \mathrm{O}\right)\right)$ and szomolnokite $\left(\mathrm{Fe}^{2+}\left(\mathrm{SO}_{4}\right) \cdot\left(\mathrm{H}_{2} \mathrm{O}\right)\right)$ were observed on Rio tailing basement.
\end{abstract}

๑) 2013 Elsevier Ltd. All rights reserved.

\section{Introduction}

Acid mine drainage (AMD) is a well-known international environmental problem related with both working and abandoned mining operations. Large masses of sulfide minerals are exposed during the mining and milling processes. The generation and discharge of AMD with low $\mathrm{pH}$ and containing high concentrations of dissolved metals may seriously disturb the water quality. The key to understand mining effects depends directly on understanding the processes that produce AMD. Acidic drainage is caused by the oxidation of sulfide minerals exposed to atmospheric oxygen. Although acid drainage is commonly associated with the extraction and processing of sulfide-bearing metalliferous ore deposits and sulfide-rich coal, AMD can occur wherever sulfide minerals are exposed to atmospheric oxygen (Blowes et al., 2003). The oxidation of pyrite is a complex hydrobiogeochemical process that adversely affects the water quality of receiving streams by producing acid waters with high metal concentrations. Sulfide ore extraction and processing enhances the rate of pyrite oxidation, increases the rate of acid production, and can cause severe environmental

\footnotetext{
* Corresponding author. Tel.: +351 938065 777; fax: +351 234370605

E-mail address: candeias@ua.pt (C. Candeias).
}

damage (Plumlee and Logsdon, 1999; Jambor et al., 2003; Nordstrom et al., 2007).

The Panasqueira mine was chosen to be studied due to several factors: (a) it is an active mine; (b) the existence of huge volumes of tailing piles and mud dams, (c) small villages near the mine site; (d) the Zêzere river crosses the area, which supply the Castelo de Bode dam (located $90 \mathrm{~km}$ downstream), the main water provider for Lisbon; and (e) the local population strongly depends on the use of land and water for their subsistence. The effect of Panasqueira mining activities and the metals release from acid mine waters to water courses is dynamic and actual (e-EcoRisk, 2007; Ávila et al., 2008; Ferreira da Silva et al., 2013; Candeias et al., 2013; Coelho et al., 2013). Regarding the study presented by Ávila et al. (2008) and its conclusions, mainly related to the dynamics of leaching, transport, and accumulation of some selected metals and metalloids in different media (stream sediments, alluvium, surface waters, impoundment materials, iron coatings, arsenopyrite stockpile material, and ferruginous crust) this study aims to characterize the heavy metal contamination at Zêzere river taking into consideration the physico-chemical properties of the waters sampled on the Zêzere river and along the mine drainage. The main goal of this geochemical research is (a) to characterize the surface water chemical changes that occur along the flow path of Zêzere 